\title{
Initial Observations on the Inclusion of High Protein Distillers Dried Grain into Rainbow Trout Diets
}

\author{
Michael E. Barnes ${ }^{1, *}$, Michael L. Brown ${ }^{2}$ and Kurt A. Rosentrater ${ }^{3}$ \\ ${ }^{I}$ McNenny State Fish Hatchery, South Dakota Department of Game, Fish and Parks 19619 Trout Loop, Spearfish, South \\ Dakota 57783 USA \\ ${ }^{2}$ Department of Wildlife and Fisheries Sciences, South Dakota State University, Brookings, SD 57007 USA \\ ${ }^{3}$ Iowa State University, Department of Agricultural and Biosystems Engineering Ames, IA 50011 USA
}

\begin{abstract}
An initial investigation into the inclusion of high protein distillers dried grain with solubles (HPDDG) in juvenile rainbow trout Oncorhynchus mykiss diets was conducted during a 36-day feeding trial. Four experimental diets containing either $10 \%$ or $20 \%$ HPDDG with supplemental amino acids, and either with or without phytase, were compared to a fish-meal-based, non-HPDDG, diet. There was no significant difference among any of the diets in total weight gain, percent weight gain, feed conversion ratio, or percent mortality. There was also no significant difference in length, weight, condition factor, hepatosomatic index, viscerosomatic index, or any fish health parameter in fishes fed any of the diets. Fillet composition, as determined by crude protein, crude lipid, water, and ash were also not significantly different from fish reared on any of the diets. Estimated protein digestibility coefficients were significantly less in the fish receiving the diet void of HPDDG compared to any of the other diets. The addition of phytase had no effect on any rearing parameters. The results suggest that HPDDG, if supplemented with essential amino acids, may be included at concentrations of at least $20 \%$ (dry weight) in rainbow trout diets and that more detailed investigation into the use of HPDDG is warranted.
\end{abstract}

Keywords: Alternative proteins, Fish feed, HPDDG, Oncorhynchus mykiss, Salmonid.

\section{INTRODUCTION}

In response to increased demand for biofuels, the fuelbased ethanol industry has grown dramatically, with over 200 ethanol plants in the USA alone producing 54 billion L of ethanol in early 2011 [1]. A result of this increase in ethanol production has been a substantial increase in the amount of distillers dried grains with solubles (DDGS) [2]. DDGS is a valuable, relatively high protein source for animal feeds [3, 4], that do not contain anti-nutritional factors found in other plant protein sources fed to fish [5-8]. Compared to other corn products, nutrients are more concentrated in DDGS [9]. However, in comparison to fish meal, the essential amino acids lysine and methionine are present in lower concentrations [10] which may require supplementation when DDGS are incorporated into fish feeds.

Conventional DDGS contains protein levels of approximately $30 \%$ [11]. However, this value varies substantially, even from batch to batch $[2,12,13]$. Higher protein distiller dried grains with solubles (HPDDG) is produced by fractionating the corn and removing the nonfermentable fractions prior to ethanol production [14], resulting in protein levels approximately $50 \%$ greater than those of DDGS pro-

*Address correspondence to this author at the McNenny State Fish Hatchery, South Dakota Department of Game, Fish and Parks 19619 Trout Loop, Spearfish, South Dakota 57783 USA; Fax: 605-642-6920, 605-642-6921; E-mail: mike.barnes@state.sd.us duced by conventional processing [15]. HPDDG nutritional values are much more consistent than conventional DDGS [15].

DDGS has been incorporated in rainbow trout Oncorhynchus mykiss diets for some time. The earliest experimentation was performed by Philips [16], and 3\% dietary DDGS was successfully used by Sinnhuber [17]. Similar to DDGS, dried distillers solubles were used by Phillips et al. [18]. Other distiller grain products produced acceptable results when incorporated into salmonids diets at low concentrations $[19,20]$. Dietary DDGS concentrations of $15 \%$ were used successfully by Cheng and Hardy [10] when fed to juvenile rainbow trout, while concentrations of $22.5 \%$ were acceptable with lysine and methionine supplementation. However, Stone et al., [21] noted that rainbow trout on fish meal control diets performed significantly better than trout receiving dietary DDGS. Cheng et al., [22] indirectly examined DDGS in rainbow trout diets. In their study, diets containing $18.5 \%$ DDGS, $17.5 \%$ soybean meal, and $17.5 \%$ fish meal, in conjunction with the use of a methionine hydroxyl analogue, produced similar rearing results as diets with $18.5 \%$ DDGS and 35\% fish meal [22]. Rainbow trout diets including plant ingredients may benefit from the inclusion of phytase to catalyze indigestible phosphorous (phytic acid) found in plant products to a digestible organic form of phosphorous [23-26]. However, not all studies have indicated a positive effect of phytase supplementation on trout growth [27, 28]. 
Little research has been conducted on the incorporation of HPDDG into fish diets, particularly with rainbow trout. In addition, little research has been conducted on the use of phytase in HPDDG-containing diets. Thus, the objective of this study was to provide an initial evaluation of the use of HPDDG, supplemented with amino acids and phytase, in juvenile rainbow trout diets.

\section{METHODS}

The trial occurred at McNenny State Fish Hatchery (Spearfish, South Dakota, USA) using degassed and aerated well water at a constant temperature of $11^{\circ} \mathrm{C}$ (total hardness as $\mathrm{CaCO}_{3}, 360 \mathrm{mg} / \mathrm{L}$; alkalinity as $\mathrm{CaCO}_{3}, 210 \mathrm{mg} / \mathrm{L} ; \mathrm{pH}$, 7.6; total dissolved solids, $390 \mathrm{mg} / \mathrm{L}$ ). Flow rates in each tank were set at $40 \mathrm{~L} / \mathrm{min}$. Shasta strain rainbow trout (initial weight $33.6 \pm 1.5 \mathrm{~g}$, length $146.7 \pm 2.1 \mathrm{~mm}$, mean $\pm \mathrm{SE}$ ) were randomly placed into each of 15 fiberglass circular tanks (1.8 m diameter, $0.6 \mathrm{~m}$ depth) on September 2, 2010. Tank were loaded with 40 fish, and total tank weights were measured to $\pm 1 \mathrm{~g}$. Feeding commenced the following day and continued for 36 days until the end of the trial. Feeding amounts for the tanks were determined by the hatchery constant (HC) method [29], with a planned feed conversion of 1.1 and a maximum growth rate of $0.066 \mathrm{~cm} /$ day, which was based on the historical performance of the Shasta strain at McNenny State Fish Hatchery. Feed amounts were updated daily. Fish were hand fed once per day. All feed fed and mortality were recorded daily for each tank.

The 15 tanks were randomly assigned to one of five different diets (Table 1), with three tanks receiving the same diet $(\mathrm{N}=3)$. In addition to a fish-meal-based, non-HPDDG diet, four other diets contained either $10 \%$ or $20 \%$ HPDDG (Poet Dakota Gold HP, Glenville East, South Dakota, USA, $41.7 \%$ protein, $4.5 \%$ lipid). To make the essential amino acid profiles similar in all of the diets and potentially improve the acceptability of dietary HPDDG [22, 30], the HPDDGcontaining diets were supplemented with lysine, methionine, isoleucine, and histidine. Dietary amino acid analysis was conducted according to AOAC [31] method 982.30 (Table 2). In addition, phytase was added to one-half of the HPDDG-containing diets. Pelleted diets were produced by extrusion processing. Experimental diets were analyzed according to AOAC [31] methodology for protein (method 2001.11) and crude lipid (method 2003.5, modified by substituting petroleum ether for diethyl ether), and ash content by AACC [32] method 08-03. The protein and lipid amounts obtained by these methods were multiplied by their respective physiological fuel values of 23.6 and $39.5 \mathrm{~mJ}$ [33] to obtain estimated digestible energy values.

At the end of the trial, total tank weights were measured to $\pm 1 \mathrm{~g}$, with weight gain calculated by subtracting the initial weight from the final weight for each tank. Feed conversion ratio for each tank was calculated by dividing the total amount of food fed by the total weight gain. In addition to total tank measurements, five fish from each of the 15 tanks (75 total) were randomly selected, euthanized, and individually weighed to $\pm 1 \mathrm{~g}$ and measured (total length) to $\pm 1 \mathrm{~mm}$. Fish health profiles, based on a modification of Goede and Barton [34], Adams et al. [35], and Barton et al. [36], were completed using the score sheet described in (Table 3). To obtain information on the energy reserve status, as well as the general health condition of the fish, hepatosomatic index (HSI) and viscerosomatic index (VSI) were calculated. To determine HSI, liver weights were recorded to $\pm 1 \mathrm{mg}$ for inclusion in the formula: HSI $(\%)=100 \times$ (liver weight [g]/whole fish weight [g]) [37]. Similarly, viscera weights were also recorded to the nearest $\mathrm{mg}$ and VSI determined using the formula: VSI $(\%)=100 \mathrm{x}$ (viscera weight $[\mathrm{g}] /$ whole fish weight $[\mathrm{g}])$. Condition factor was calculated as $\mathrm{K}=10^{5} \mathrm{x}$ (weight $\left.[\mathrm{g}]\right) /\left(\right.$ length $^{3}[\mathrm{~mm}]$ ).

To quantify the digestibility of dietary protein, apparent protein digestability was determined using a direct method [38]. Digesta was removed from five fish per tank at the end of the trial. Each fish was dissected and the last $1 \mathrm{~cm}$ of the distal end of the intestine was gently squeezed to remove the contents. Digesta from five fish per tank was pooled and flash frozen on dry ice prior to analysis. Protein analysis was conducted using AOAC [31] method 990.03. Apparent protein digestability was calculated using the formula: apparent protein digestability $(\%)=$ (protein in the diet - protein in the digesta) / protein $\mathrm{x} 100$ in the diet.

Muscle fillets were removed and flash frozen for determination of carcass composition. The fillets from each tank were pooled and analyzed for crude protein levels with a TruSpec CNS combustion analyzer (LECO Corp., St. Joseph, Michigan, USA) using AOAC [31] method 992.15. AOAC [31] acid hydrolysis method 948.15 with a 50:50 mix of diethyl ether and petroleum ether for extraction was used for fat analysis. Moisture was determined by loss on drying using AOAC [31] method 952.08.

Data were analyzed using the SPSS (9.0) with significance predetermined at $P<0.05$. One-way analysis of variance (ANOVA) was conducted, and if the treatments were significantly different, pairwise mean comparisons were performed using the Tukey HSD test [39]. Mortality (\%) data were arcsine transformed prior to analysis to stabilize the variances [39].

\section{RESULTS}

There was no significant difference in fish rearing performance measures among any of the diets evaluated (Table 4). Mean weight gain, percent weight gain, and food conversion ratio were nearly identical in the diets containing HPDDG compared to the fish-meal-based diet. The mean estimated digestion coefficient of protein was significantly different among the different diets. It ranged from $93.4 \%$ to $94.1 \%$ in the fish fed diets with HPDDG, which was significantly greater than the $91.4 \%$ value for fish receiving the fish-meal-based diet. Dietary phytase had no significant effect on weight gain, conversion, or protein digestibility. No differences in mortality were detected as only one mortality was observed during the experiment.

Individual fish parameters were also very similar among the diets (Table 5). No significant differences were detected among treatments for length, weight, or condition factor. The viscerosomatic index and hepatosomatic index were also not significantly different. None of the fish health values varied significantly among the fish receiving any of the diets. There was no gut inflammation observed in any fish. 
Table 1. Ingredients Composition (\%) and Chemical Analysis of the Diets Used in the Trial

\begin{tabular}{|c|c|c|c|c|c|}
\hline Diet & 1 & 2 & 3 & 4 & 5 \\
\hline HPDDG (\%) & 0 & 10 & 10 & 20 & 20 \\
\hline Phytase supplement & no & no & yes & no & yes \\
\hline \multicolumn{6}{|l|}{ Ingredients } \\
\hline Menhaden meal ${ }^{\mathrm{a}}$ & 40.0 & 40.0 & 40.0 & 30.0 & 30.0 \\
\hline HPDDG $^{b}$ & 0.0 & 10.0 & 10.0 & 20.0 & 20.0 \\
\hline Whole wheat ${ }^{c}$ & 20.0 & 11.0 & 11.0 & 11.0 & 11.0 \\
\hline Yellow corn gluten ${ }^{\mathrm{d}}$ & 25.0 & 20.0 & 20.0 & 20.0 & 20.0 \\
\hline Menhaden oil $^{\mathrm{e}}$ & 11.5 & 11.5 & 11.5 & 12.0 & 12.0 \\
\hline $\mathrm{CMC}^{\mathrm{f}}$ & 0.6 & 0.0 & 0.0 & 0.0 & 0.0 \\
\hline Vitamin premix ${ }^{g}$ & 0.5 & 0.5 & 0.5 & 0.5 & 0.5 \\
\hline Mineral premix ${ }^{\mathrm{h}}$ & 0.0 & 0.1 & 0.1 & 0.1 & 0.1 \\
\hline Vitamin C $(\text { Stay-C })^{\mathrm{i}}$ & 0.5 & 0.5 & 0.5 & 0.5 & 0.5 \\
\hline Phytase $^{\mathrm{j}}$ & 0.0 & 0.0 & 0.037 & 0.0 & 0.037 \\
\hline Yeast $^{\mathrm{k}}$ & 0.125 & 0.125 & 0.125 & 0.125 & 0.125 \\
\hline L-Lysine $^{1}$ & 0.0 & 0.5 & 0.5 & 0.5 & 0.5 \\
\hline L-Isoleucine $^{1}$ & 0.0 & 0.3 & 0.3 & 0.3 & 0.3 \\
\hline L-Histidine $^{1}$ & 0.0 & 0.1 & 0.1 & 0.1 & 0.1 \\
\hline L-Methionine $^{1}$ & 0.0 & 0.5 & 0.5 & 0.5 & 0.5 \\
\hline Sodium chloride & 0.5 & 0.9 & 0.9 & 0.9 & 0.9 \\
\hline Potassium chloride & 0.6 & 0.7 & 0.7 & 0.7 & 0.7 \\
\hline Magnesium oxide & 0.0 & 0.1 & 0.1 & 0.1 & 0.1 \\
\hline Calcium phosphate dibasic & 0.0 & 2.3 & 2.3 & 2.3 & 2.3 \\
\hline \multicolumn{6}{|l|}{ Chemical analysis ( $\%$ dry basis) ${ }^{1}$} \\
\hline Crude protein & 45.3 & 46.8 & 44.9 & 44.2 & 46.8 \\
\hline Crude lipid & 10.7 & 14.6 & 14.3 & 15.4 & 15.7 \\
\hline Crude fiber & 1.3 & 1.0 & 1.4 & 1.3 & 1.0 \\
\hline Ash & 10.5 & 11.8 & 10.2 & 10.1 & 11.6 \\
\hline DE (MJ kg ${ }^{-1}$ dry matter) & 14.92 & 16.81 & 16.24 & 16.51 & 17.25 \\
\hline
\end{tabular}

${ }^{a}$ IPC 740, Scoular, Minneapolis, Minnesota, USA.

${ }^{\mathrm{b}}$ BPX-HP, Poet Nutrition, Sioux Falls, South Dakota, USA.

${ }^{\mathrm{c}}$ Bob's Red Mill Natural Foods, Milwaukie, Oregon, USA.

${ }^{\mathrm{d}}$ Consumers Supply Distributing, Sioux City, Iowa, USA.

${ }^{\mathrm{e}}$ Omega Protein, Inc., Houston, Texas, USA.

${ }^{\mathrm{f}}$ Carboxymethyl cellulose.

${ }^{g}$ ARS 702, [87].

${ }^{\mathrm{h}}$ ARS 640, [87].

${ }^{i}$ DSM Nutritional Products France SAS, Village-Neuf, France.

${ }^{\mathrm{j}}$ Ronozyme P-CT, DSM Nutritional Products, Basel, Switzerland.

${ }^{\mathrm{k}}$ Diamond V, Cedar Rapids, Iowa, USA.

${ }^{1}$ PureBulk, Roseburg, Oregon, USA

Analysis conducted on post-extrusion pellets.

Table 2. Amino Acid Composition (\%, Dry Weight) of the Diets Used in the Trial, and of the Dietary Ingredient High Protein Distillers Dried Grain (HPDDG)

\begin{tabular}{|c|c|c|c|c|}
\hline Diet & $\mathbf{1}$ & $\mathbf{2}$ and 3 & 4 and 5 & HPDDG \\
\hline \hline HPDDG $(\%)$ & 0 & 10 & yes & \\
\hline Phytase & no & no & & \\
\hline Essential amino acids & & & 2.07 & 1.41 \\
\hline Arginine & 2.19 & 2.16 & \\
\hline
\end{tabular}


Table 2. cont....

\begin{tabular}{|c|c|c|c|c|}
\hline Diet & 1 & 2 and 3 & 4 and 5 & HPDDG \\
\hline Isoleucine & 1.83 & 2.10 & 2.10 & 1.52 \\
\hline Leucine & 4.79 & 4.62 & 4.77 & 5.20 \\
\hline Lysine & 2.32 & 2.75 & 2.57 & 1.14 \\
\hline Threonine & 1.57 & 1.60 & 1.53 & 1.36 \\
\hline Tryptophan & 0.40 & 0.39 & 0.40 & 0.21 \\
\hline Valine & 2.13 & 2.13 & 2.15 & 2.01 \\
\hline \multicolumn{5}{|c|}{$\underline{\text { Nonessential amino acids }}$} \\
\hline Glutamic acid & 7.91 & 7.46 & 7.26 & 6.56 \\
\hline Glycine & 2.36 & 2.46 & 2.40 & 1.41 \\
\hline Hydroxylysine & 0.08 & 0.09 & 0.07 & 0.00 \\
\hline Hydroxyproline & 0.37 & 0.41 & 0.00 & 0.00 \\
\hline Lanthionine & 0.12 & 0.11 & 0.14 & 0.26 \\
\hline Orthonine & 0.03 & 0.03 & 0.04 & 0.02 \\
\hline Proline & 3.11 & 2.93 & 2.98 & 3.25 \\
\hline Serine & 1.75 & 1.74 & 1.53 & 1.56 \\
\hline
\end{tabular}

Table 3. Criteria Used at the End of the Study for Fish Health Observations [based on Goede and Barton [34], Adams et al. [35], and Barton et al. [36]

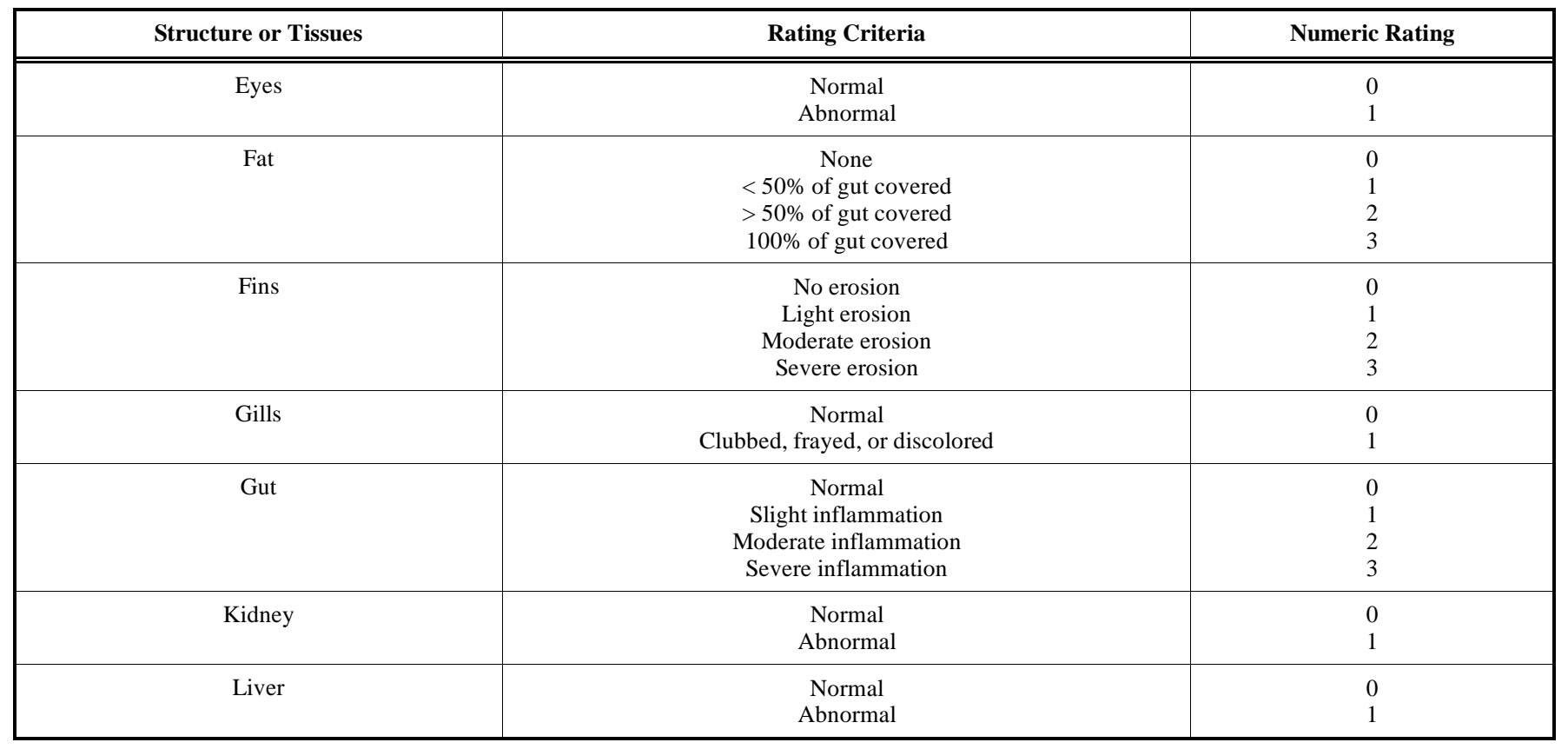


Table 3. cont...

\begin{tabular}{|c|c|c|}
\hline Structure or Tissues & Rating Criteria & Numeric Rating \\
\hline \hline Pseudobranchs & Normal & 0 \\
& Abnormal & 0 \\
\hline Opercles & Normal & 1 \\
& Short & 0 \\
\hline Spleen & Normal & 1 \\
& Cysts or enlarged & \\
\hline
\end{tabular}

Table 4. Total Tank Rearing Data (Means + SE), Including Feed Conversion Ratio (FCR) and Estimated Digestion Coefficient of Protein (DCP) for Tanks of Rainbow Trout Receiving One of five Different Diets Containing Either 10\% or 20\% High Protein Distillers Dried Grain (HPDDG), with or Without Phytase. Means in a Row with Different Letters are Significantly Different $(\mathbf{N}=3, P<0.05)$

\begin{tabular}{|c|c|c|c|c|c|}
\hline Diet & 1 & 2 & 3 & 4 & 5 \\
\hline Phytase supplement & no & no & yes & no & yes \\
\hline Start Weight (g) & $1,218 \pm 77$ & $1,306 \pm 16$ & $1,234 \pm 33$ & $1,315 \pm 59$ & $1,309 \pm 19$ \\
\hline End Weight (g) & $2,229 \pm 76$ & $2,335 \pm 41$ & $2,244 \pm 46$ & $2,367 \pm 54$ & $2,347 \pm 37$ \\
\hline Gain (g) & $1,011 \pm 17$ & $1,029 \pm 26$ & $1,010 \pm 70$ & $1,051 \pm 7$ & $1,038 \pm 18$ \\
\hline Food fed (g) & 834 & 834 & 834 & 834 & 834 \\
\hline FCR & $0.82 \pm 0.01$ & $0.81 \pm 0.02$ & $0.83 \pm 0.06$ & $0.79 \pm 0.05$ & $0.80 \pm 0.01$ \\
\hline$\%$ mortality & $0.0 \pm 0.0$ & $0.0 \pm 0.0$ & $0.0 \pm 0.0$ & $0.8 \pm 1.4$ & $0.0 \pm 0.0$ \\
\hline DCP & $91.4 \pm 0.1^{\mathrm{a}}$ & $94.1 \pm 0.1^{\mathrm{b}}$ & $93.4 \pm 0.1^{\mathrm{b}}$ & $93.7 \pm 0.1^{\mathrm{b}}$ & $93.4 \pm 0.1^{\mathrm{b}}$ \\
\hline
\end{tabular}

Table 5. Ending Mean $\left( \pm\right.$ SE) Lengths, Weights, Condition Factors $(K)^{\text {a }}$, Liver Weights, Hepatosomatic Index Values (HSI), Viscera Weights, Viscerosomatic Index (VSI) and Fish Health Assessments ${ }^{b}$ of Rainbow Trout Fed Diets Containing Either $10 \%$ or $20 \%$ High Protein Distillers Dried Grains (HPDDG), with or without Phytase $(\mathbf{N}=3)$

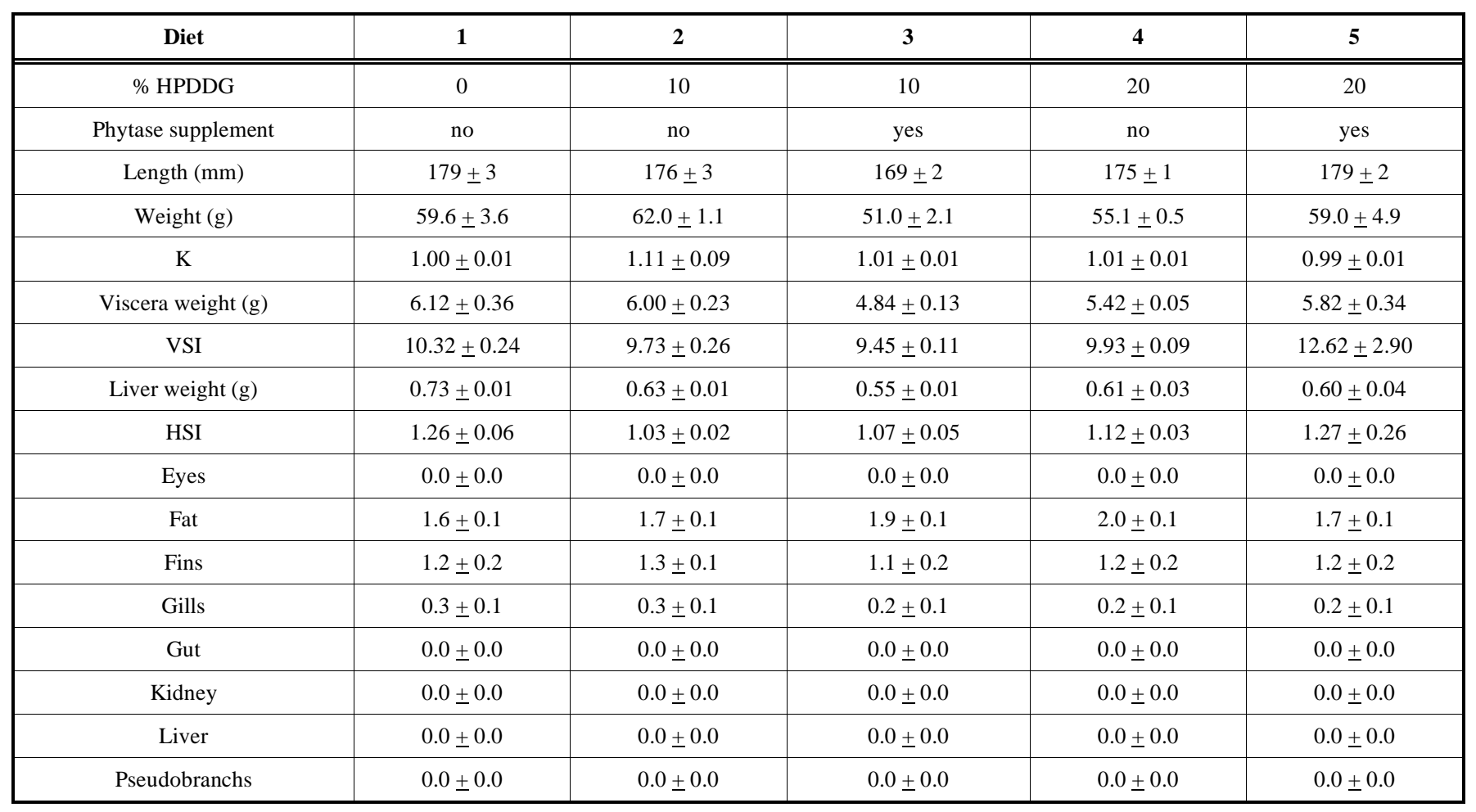


Table 5. cont.....

\begin{tabular}{|c|c|c|c|c|c|}
\hline Diet & $\mathbf{1}$ & $\mathbf{2}$ & $\mathbf{3}$ & $\mathbf{4}$ & $\mathbf{5}$ \\
\hline \hline Opercles & $0.2 \pm 0.1$ & $0.2 \pm 0.1$ & $0.2 \pm 0.1$ & $0.2 \pm 0.1$ & $0.2 \pm 0.1$ \\
\hline Spleen & $0.0 \pm 0.0$ & $0.0 \pm 0.0$ & $0.0 \pm 0.0$ & $0.0 \pm 0.0$ & $0.0 \pm 0.0$ \\
\hline
\end{tabular}

${ }^{\text {a }}$ Condition factor $(\mathrm{K})=10^{5} \mathrm{x}$ (weight $\left.[\mathrm{g}]\right) /\left(\right.$ length $\left.{ }^{3}[\mathrm{~mm}]\right)$

${ }^{\mathrm{b}}$ Fish health assessments rating system described in Table $\mathbf{2}$.

Table 6. Mean $( \pm$ SE) Percent Water, Crude Protein, Crude Lipid, and Ash Concentrations from Fillets of Rainbow Trout Fed Diets Containing Either $10 \%$ or $20 \%$ High Protein distillers Dried Grains (HPDDG), with or Without Phytase $(\mathbf{N}=3)$

\begin{tabular}{|c|c|c|c|c|c|}
\hline Diet & 1 & 2 & 3 & 4 & 5 \\
\hline Phytase supplement & no & no & yes & no & yes \\
\hline Water $(\%)$ & $77.3 \pm 1.5$ & $76.2 \pm 0.8$ & $76.4 \pm 0.3$ & $75.9 \pm 0.3$ & $75.3 \pm 0.3$ \\
\hline Crude protein $(\%)$ & $18.6 \pm 0.5$ & $19.1 \pm 0.2$ & $19.0 \pm 0.3$ & $19.1 \pm 0.2$ & $19.1 \pm 0.2$ \\
\hline Crude lipid (\%) & $4.6 \pm 0.2$ & $4.2 \pm 0.9$ & $4.4 \pm 0.5$ & $3.6 \pm 0.2$ & $3.8 \pm 0.1$ \\
\hline
\end{tabular}

Fillet composition was not significantly affected by any of the diets used in this study (Table 6). Fillet protein percentages ranged from $18.6 \%$ in fish fed the fish meal control to $19.0 \%$ and $19.1 \%$ in fish receiving feed with HPDDG. Although not significantly different, mean fillet lipid percentages were $4.6 \%$ in the fish-meal-based diet and were less than $4.0 \%$ in the fish fed the highest dietary concentrations of HPDDG.

\section{DISCUSSION}

The inclusion of up to $20 \%$ dietary HPDDG with no negative effects on growth or conversion is similar to that reported by Cheng and Hardy [10] with lower protein, conventional DDGS. They noted no deleterious effects of up to $22.5 \%$ inclusion in rainbow trout diets containing conventional DDGS, with lysine and methionine supplementation. In contrast, Stone et al. [21] noted deficiencies in diets with conventional DDGS compared to a fish meal control.

Phytase supplementation had no effect on growth or feed conversion in the fish fed diets containing HPDDG. However, these results are difficult to interpret because it is unknown how much phytate (phytic acid salts or esters that interfere with phosporous absorption) was present in the HPDDG, the experimental diets were likely not phosphorous-limited, the efficiency of phytase may be somewhat dependent on the method used to incorporate it into the feed [40], and the phytase may have been deactivated during extrusion [41]. Cheng and Hardy [25] also observed no improvements in growth or feed conversion in rainbow trout receiving diets containing $15 \%$ DDGS and varying amounts of phytase. Rainbow trout growth was also unaffected by phytase supplementation in diets containing soy [28] or canola protein concentrate [27]. However, phytase did enhance rainbow trout growth when included in soybean-based diets $[23,24,26]$. Dietary phytase supplementation in higher quality diets of fish species other than rainbow trout has generally had no positive effect on growth and feed conversion ratio [40, 42-44], except in common carp Cyprinus carpio [45, 46] and Nile tilapia Oreochromis niloticus [47]. Although it was not measured in this study, phytase has been repeatedly shown to increase the availability of phosphorous in fish feeds containing plant (primarily soybean) ingredients [48-52].

Similar to the results obtained by Cheng and Hardy [25] who used lower protein conventional DDGS, phytase supplementation did not improve the estimated digestibility of protein. Cheng and Hardy [25] suggested that this was due to the relatively high protein digestibility of the DDGS observed in their study. The over $93 \%$ estimated protein digestibility in this study was even greater than that observed by Cheng and Hardy [25]. This significant improvement in protein digestibility of the diets containing HPDDG compared to the fish meal control can likely be attributed to amino acid supplementation [53-56].

Fillet lipid concentrations did not increase with increasing HPDDG in this study. In contrast, increased lipid levels were observed with the dietary DDGS inclusion by Lim et al. [57] and Li et al. [58]. However, Johnsen et al. [59] did not observe increased lipid concentrations in Atlantic salmon Salmo salar fed low fish meal, high fat diets in comparison to those receiving high fish meal, low fat feeds. Fillet protein concentrations were also unaffected by diet in this study. $\mathrm{Li}$ et al. [58] and Li et al. [60] also reported decreased fillet protein composition in channel catfish Ictalurus punctatus fed either fish meal or DDGS-containing diets. The percent moisture and crude protein of fillets from the trout receiving the control, fish-meal only diet were very similar to that reported by Yildiz [61], but less than that reported by Sealey et al. [62]. However, the rainbow trout fillets analyzed by Sealey et al. [62] came from fish that were fed a $29 \%$ fish meal control diet that also contained $16 \%$ soybean meal. Additional differences between this study and Sealey et al. [62], such as feeding rates and fish sizes, may also explain the differences in fillet composition. 
Although the hepatosomatic index is positively related to carbohydrate levels in the diet [63,64], there was no increase in HSI as dietary HPDDG levels increased. Hepatosomatic index either slightly decreased, or showed no effect, from dietary HPDDG in tilapia Oreochromis niloticus [65, 66], and was also unaffected by dietary protein in common carp Cyprinus carpio [67]. Because dietary phosphorus is inversely related to liver lipid levels and HSI, [68], the lack of difference in HSI among the diets would appear to indicate no deficiencies in phosphorus availability from any of the diets, regardless of phytase supplementation.

VSI was unaffected by changes in diet, even though the experimental diets contained lipid levels greater than that of the control. Other studies have noted an increase in VSI with increasing dietary lipid levels [69-71].

The relatively low feed conversion ratios for both the control and treatment diets are not unusual for production rainbow trout of this size at hatcheries in South Dakota [72] or elsewhere [73]. They could also be explained by the low rearing densities used in the trial $[74,75]$, which were due to the size of the tanks available for experimentation and the limited quantity of feed that could be manufactured. Feeding rates may also have influenced feed conversion ratio results.

Because of the often dramatic differences in conventional DDGS nutritional composition [2, 12, 13], it may be difficult to compare the results between studies examining DDGS use in rainbow trout diets. In comparison to conventional DDGS, HPDDG is more nutritionally consistent [15]. Other factors, such as feed production techniques [76-78], water temperature [79-81], other dietary ingredients, such as soybean meal [10], and fish size, may also potentially effect diet performance and contribute to differing results in DDGS-related studies.

In conclusion, the results from this introductory shortterm study indicate that HPDDG with amino acid supplementation may be successfully incorporated at up to $20 \%$ in juvenile rainbow trout grower diets, thereby warranting additional, longer-term, studies. With the rapid growth in global aquaculture [82] and the increased demand and market prices for limited fish meal stocks $[83,84]$ and other agricultural commodities, HPDDG could provide an additional and effective lower-cost protein source for the diets of carnivorous aquaculture fish species, such as trout and perhaps other salmonids $[10,33,85,86]$.

\section{CONFLICT OF INTEREST}

None declared.

\section{ACKNOWLEDGEMENTS}

The authors thank the Agriculture Experiment Station, South Dakota State University, South Dakota Department of Game, Fish and Parks, and the North Central Agricultural Research Laboratory, USDA-ARS, Brookings, South Dakota, for funding, facilities, equipment, and supplies. Furthermore, the assistance of Parisa Fallahi, Eric Krebs, Kamal Mjoun, Rilie Morgan, Patrick Nero, Sharon Nichols, Jill Tycz, Mehmet Tulbek, and Sarah Zimmerman is greatly appreciated.

\section{REFERENCES}

[1] Renewable Fuels Association (RFA), 2011. Biorefinery Locations. $11^{\text {th }}$ May 2011. Available from: http://www.ethanolrfa.org/biorefinery-locations.

[2] Rosentrater KA, Muthukumarappan K. Corn ethanol coproducts: Generation properties, and future prospects. Int Sugar J 2006; 108: 648-57.

[3] Wu YV, Rosati RR, Brown PB. Use of corn-derived ethanol products and synthetic lysine and tryptophan for growth of tilapia (Oreochromis niloticus) fry. J Agric Food Chem 1997; 45: 2174-7.

[4] Ganesan V, Rosentrater KA, Muthukumarappan K. Flowability and handling characteristics of bulk solids and powders - a review with implication for DDGS. Biosys Eng 2008; 101: 425-35.

[5] Jauncey K, Ross B. A Guide to Tilapia feeds and feeding. Institute of Aquaculture, University of Stirling, Stirling, Scotland 1982.

[6] Wilson RP, Poe WE. Effects of feeding soybean meal with varying trypsin inhibitor activities on growth of fingerling channel catfish. Aquaculture 1985; 46: 19-25.

[7] Shiau SY, Chuang, JL, Sun GL. Inclusion of soybean meal in tilapia (Oreochromis niloticus $\times$ O. aureus) diets at two protein levels. Aquaculture 1987; 65: 251-61.

[8] Robinson EH. Improvement of cottonseed meal protein with supplemental lysine in feeds for channel catfish. J Appl Aquacult 1991; 1: 1-14.

[9] Chevanan N, Rosentrater KA, Muthukumarappan K. Effect of DDGS, moisture content, and screw speed on the physical properties of extrudates in single screw extrusion. Cereal Chem 2008; 85(2):132-9.

[10] Cheng ZJ, Hardy RW. Nutritional value of diets containing distiller's dried grain with solubles for rainbow trout, Oncorhynchus mykiss. J Appl Aquacult 2004; 15: 101-13.

[11] Spiehs MJ, Whitney MH, Shurson GC. Nutrient database for distiller's dried grains with solubles produced from new ethanol plants in Minnesota and South Dakota. J Anim Sci 2002; 80: 2639-45.

[12] Belyea RL, Eckhoff SR, Wallig MA, Tumbleson ME. Variability in the nutritional quality of distillers solubles. Bioresour Technol 1998; 66: 207-12.

[13] Abo-State HA, Tahoun AM, Hammouda YA. Effect of replacement of soybean by DDGS combined with commercial phytase on Nile tilapia (Oreochromis niloticus) fingerlings growth performance and feed utilization. Am-Eurasian J Agric Environ Sci 2009; 5: 473-9.

[14] Singh W, Johnston DB, Naidu K, Raush KD, Belyea RL, Tumbleson ME. Comparison of modified dry-grind corn processes for fermentation characteristics and DDGS composition. Cereal Chem 2005; 82: 187-90.

[15] Robinson PH, Karges K, Gibson ML. Nutritional evaluation of four co-product feedstuffs from the motor fuel ethanol distillation industry in the Midwestern USA. Anim Feed Sci Technol 2008; 146: 345-52.

[16] Phillips AM. Fish Res Bull No. 13. Cortland Hatchery Reports No. 18. Cortland, NY, USA, 1949.

[17] Sinnhuber RO. Pelleted fish food. Feedstuffs 1964; 36(28): 16.

[18] Phillips AM, Hammer GL, Edwards JP, Hosking HF. Dry concentrates as complete trout foods for growth and egg production. Prog Fish-Cult 1964; 26: 155-9.

[19] Fowler LG, Banks JL. Fish meal and wheat germ substitutes in the Abernathy diet. Prog Fish-Cult 1976; 38: 127-30.

[20] Hughes SG. Distillers products in salmonid diets. Proc. Distillers Feed Conf 1987; 42: 27-31.

[21] Stone DA, Hardy RW, Barrows FT, Cheng ZJ. Effects of extrusion on nutritional value of diets containing corn gluten meal and corn distiller's dried grain for rainbow trout Oncorhynchus mykiss. J Appl Aquacult 2005; 17: 1-20.

[22] Cheng ZJ, Hardy RW, Blair M. Effects of supplementing methionine hydroxyl analogue in soybean meal and distillers dried grain-based diets on the performance and nutrient retention of rainbow trout [Oncorhynchus mykiss (Walbaum)]. Aquacult Res 2003; 34: $1303-10$.

[23] Lanari D, D'Agaro E, Turri C. Use of nonlinear regression to evaluate the effects of phytase enzyme treatment of plant protein diets for rainbow trout (Oncorhynchus mykiss). Aquaculture 1998; 161: 345-56.

[24] Vielma J, Lall SP, Koskela J, Schoner FJ, Mattila P. Effects of dietary phytase and cholecalciferol on the trace element metabo- 
lism by rainbow trout (Oncorhynchus mykiss). Aquaculture 1998; 163: 309-23.

[25] Cheng ZJ, Hardy RW. Effect of microbial phytase supplementation in corn distiller's dried grain with solubles on nutrient digestibility and growth performance of rainbow trout, (Oncorhynchus mykiss). J Appl Aquacult 2004; 15: 83-100.

[26] Dalsgaard J, Ekmann KS, Pedersen PB, VerlhacV. Effect of supplemented fungal phytase on performance and phosphorus availability by phosphorus-depleted juvenile rainbow trout (Oncorhynchus mykiss), and on the magnitude and composition of phosphorus waste output. Aquaculture 2009; 286: 105-12.

[27] Forster I, Higgs DA, Dosanjh BS, Rowshandeli M, Parr J. Potential for dietary phytase to improve the nutritive value of canola protein concentrate and decrease phosphorous output in rainbow trout $(\mathrm{On}$ corhynchus mykiss) held in $11^{\circ} \mathrm{C}$ fresh water. Aquaculture 1999; 179: 109-25.

[28] Vielma J, Mäkinen T, Ekholm P, Koskela J. Influence of dietary soy and phytase levels on performance and body composition of large rainbow trout (Oncorhynchus mykiss) and algal availability of phosphorous load. Aquaculture 2000; 183: 349-62.

[29] Buterbaugh GL, Willoughby H. A feeding guide for brook, brown and rainbow trout. Prog Fish-Cult 1967; 29: 210-15.

[30] Cheng ZJ, Hardy RW, Usry JL. Effects of lysine supplementation in plant protein-based diets on the performance of rainbow trout (Oncorhynchus mykiss) and apparent digestibility coefficients of nutrients. Aquaculture 2003; 215: 255-65.

[31] Association of Official Analytical Chemists (AOAC). Official Methods of for Analysis, (online version); 2009 [cited 20 ${ }^{\text {th }}$ Oct 2011]. Available from: http://www.eoma.aoac.org/.

[32] American Association of Cereal Chemists (AACC). Approved Methods of the American Association of Cereal Chemists. $10^{\text {th }}$ ed. St. Paul, MN, USA: American Association of Cereal Chemists 2000 .

[33] NRC. Nutrient requirements of fish. Washington D.C., USA: National Academy Press 1993.

[34] Goede RW, Barton BA. Organismic indices and an autopsy-based assessment as indicators of health and condition in fish. In: Adams, SM, Eds. Biological indicators of stress in fish. Bethesda, Maryland, USA. Symposium 8. Am Fish Soc Symp 1990; 93-108.

[35] Adams SM, Brown AM, Goede RW. A quantitative health assessment index for rapid evaluation of fish condition in the field. Trans Am Fish Soc 1993; 122: 63-73.

[36] Barton BA, Morgan JD, Vijayan MM. Physiological and conditionrelated indicators of environmental stress in fish. In: Adams SM, Eds Biological indicators of aquatic ecosystem stress. Bethesda, Maryland, USA: Am Fish Soc 2002; pp. 111-48.

[37] Strange RJ. Field examination of fishes. In: Murphy BR, Willis DW, Eds. Fisheries techniques. $2^{\text {nd }}$ ed, Bethesda Maryland, USA: Am Fish Soc 1996; pp. 433-66.

[38] Windell JT, Foltz JW, Sarokon JA. Method of faecal collection and nutrient leaching in digestibility studies. Prog Fish-Cult 1978; 40: 51-5.

[39] Kuehl RO. Design of experiments: statistical principles of research design and analysis. $2^{\text {nd }}$ ed. Pacific Grove, California, USA: Brookes-Cole 2000.

[40] Denstadli V, Storebakken T, Svihus B, Skrede A. A comparison of online phytase pre-treatment of vegetable feed ingredients and phytase coating in diets for Atlantic salmon (Salmo salar L.) reared in cold water. Aquaculture 2007; 269: 414-26.

[41] Cao L, Wang W, Yang C, et al. Application of microbial phytase in fish feed. Enzyme Microb. Technol. 2007; 40: 497-507.

[42] Sajjadi M, Carter CG. Dietary phytase supplementation and the utilization of phosphorus by Atlantic salmon (Salmo salar L.) fed a canola-meal-based diet. Aquaculture 2004; 240: 417-31.

[43] Yoo G-Y, Wang X, Choi S, Han K, Kang J-C, Bai SC. Dietary microbial phytase increased the phosphorous digestibility in juvenile Korean rockfish Sebaste schlegeli fed diets containing soybean meal. Aquaculture 2005; 243: 315-22.

[44] Lim S-J, Lee K-J. Partial replacement of fish meal by cottonseed meal and soybean meal with iron and phytase supplementation for parrot fish Oplegnathus fasciatus. Aquaculture 2009; 290: 283-9.

[45] Nwanna RE, Schwarz FJ. Effect of supplemental phytase on growth, phosphorous digestibility and bone mineralization of common carp (Cyprinus carpio L). Aquacult Res 2007; 38: 103744.
[46] Nwanna RE, Eisenreich R, Schwarz FJ. Effect of wet-incubation of dietary plant feedstuffs with phytases on growth and mineral digestibility by common carp (Cyprinus carpio L). Aquaculture 2007; 271: 461-8.

[47] Liebert F, Portz L. Nutrient utilization and Nile tilapia Oreochromis niloticus fed plant based low phosphorus diets supplemented with graded levels of different sources of microbial phytase. Aquaculture 2005; 248: 111-9.

[48] Cain KD, Garling DL. Pre-treatment of soybean meal with phytase for salmonids diets to reduce phosphorus concentrations in hatchery effluents. Prog Fish-Cult 1995; 57: 114-9.

[49] Jackson LS, Li MH, Robinson EH. Use of microbial phytase in channel catfish Ictalurus punctatus diets to improve utilization of phytate phosphorus. J World Aqucult Soc 1996; 27: 309-13.

[50] $\mathrm{Li} \mathrm{MH}$, Robinson EH. Microbial phytase can replace inorganic phosphorus supplements in channel catfish Ictalurus punctatus diets. J World Aquacult Soc 1997; 18: 402-6.

[51] Rodehutscord M, Pfeffer E. Effects of supplemental microbial phytase on phosphorus digestibility and utilization in rainbow trout (Oncorhynchus mykiss). Water Sci Technol 1995; 31: 143-7.

[52] Sugiura SH, Gabaudan J, Dong FM, Hardy RW. Dietary microbial phytase supplementation and the utilization of phosphorus, trace minerals and protein by rainbow trout [Oncorhynchus mykiss (Walbaum)] fed soybean meal-based diets. Aquacult Res 2001; 32: 583-92.

[53] Krogdahl A, Lea TB, Olli JJ. Soybean proteinase inhibitors affect intestinal typsin activities and amino acid digestibilities in rainbow trout (Oncorhynchus mykiss). Comp Biochem Physiol Part A: Physiol 1993; 107: 215-9.

[54] Pongmaneerat J, Watanabe T, Takeuchi T, Satoh S. Use of different protein meals as partial or total substitution for fish meal in carp diets. Bull Jap Soc Sci Fish 1993; 59: 1249-57.

[55] Rodehutscord M, Becker A, Pack M, Pfeffer E. Response of the rainbow trout (Oncorhynchus mykiss) to supplements of individual essential amino acids in a semipurified diet, including an estimate of the maintenance requirement for essential amino acids. Nutrition 1997; 127: 1166-75.

[56] Yamamoto T, Sugita T, Furuita H. Essential amino acid supplementation to fish meal-based diets with low protein to energy ratios improves the protein utilization in juvenile rainbow trout $\mathrm{On}$ corhynchus mykiss. Aquaculture 2005; 246: 379-91.

[57] Lim C, Yildririm-Aksoy M, Klesius PH. Growth response and resistance to Edwarsiella ictaluri of channel catfish, Ictalurus punctatus, fed diets containing distiller's dried grains with solubles. J World Aquacult Soc 2009; 40: 182-93.

[58] Li MH, Robinson EH, Oberle DF, Lucas PM. Effects of various corn distillers by-products on growth, feed efficiency, and body composition of channel catfish, Ictalurus punctatus. Aquacult Nutr 2010; 16: 188-93.

[59] Johnson CA, Hagen Ø, Bendiksen EÁ. Long-term effects of highenergy, low-fishmeal feeds on growth and flesh characteristics of Atlantic salmon (Salmo salar L.). Aquaculture 2011; 312: 109-16.

[60] Li MH, Oberle DF, Lucas PM. Evaluation of corn distillers dried grains with solubles and brewers yeast in diets for channel catfish Ictalurus punctatus (Rafinesque). Aquacult Res 2011; 42: 1424-30.

[61] Yildiz M. The study of fillet quality and the growth performance of rainbow trout (Oncorhynchus mykiss) fed with diets containing different amounts of vitamin E. Turkish J Fish Aquat Sci 2004; 4: 816.

[62] Sealey WM, Gaylord TG, Barrows FT, et al. Sensory analysis of rainbow trout, Oncorhynchus mykiss, fed enriched black soldier fly prepupae, Hermetia illucens. J World Aquacult Soc 2011; 42: 3445.

[63] Daniels WH, Robinson EH. Protein and energy requirements of juvenile red drum (Sciaenops ocellatus). Aquaculture 1986; 53: 243-52.

[64] Kim JD, Kaushik SJ. Contributions of digestible energy from carbohydrates and estimation of protein/energy requirements for growth of rainbow trout (Oncorhynchus mykiss). Aquaculture 1992; 106: 161-9.

[65] Schaeffer TW, Brown ML, Rosentrater KA. Performance characteristics of Nile tilapia (Oreochromis niloticus) fed diets containing graded levels of fuel-based distillers dried grains with solubles. J Aquacult Feed Sci Nutr 2009; 1(4): 78-83.

[66] Schaeffer TW, Brown ML, Rosentrater KA, Muthukumarappan K. Utilization of diets containing graded levels of ethanol production 
co-products by Nile tilapia. J Anim Physiol Anim Nutr 2010; 94: 348-54.

[67] Fine M, Zilberg D, Cohen Z, Degani G, Moav B, Gertler A. The effect of dietary protein level, water temperature and growth hormone administration on growth and metabolism in the common carp (Cyprinus carpio). Comp Biochem Physiol 1996; 114A: 3542.

[68] Sakamota S, YoneY. Effect of dietary phosphorus level on chemical composition of red sea bream. Bull Jap Soc Sci Fish 1978; 44: 227-9.

[69] Jobling M, Koskela J, Savolainen R. Influence of dietary fat level and increased adiposity on growth and fat deposition in rainbow trout, Oncorhynchus mykiss (Walbaum). Aquacult Res 1998; 29: 601-7.

[70] Company R, Calduch-Giner JA, Kaushik S, Perez-Sanchez J. Growth performance and adiposity in gilthead sea bream (Sparus aurata): risks and benefits of high energy diets. Aquaculture 1999; 171: 279-92.

[71] Yildiz M, Sener E, Timur M. Effect of seasonal change and different commercial feeds on proximate composition of sea bream (Sparus aurata). Turkish J Fish Aquat Sci 2006; 6: 99-104.

[72] Barnes ME, Wintersteen K, Krebs, E, et al. McNenny State Fish Hatchery Annual Production Report. USA: South Dakota Department of Game, Fish and Parks 2011.

[73] Figueiredo-Silva AC, Rema P, Bandarra NM, Nunes ML, Valente LMP. Effects of dietary conjugated linoleic acid on growth, nutrient utilization, body composition, and hepatic lipogenesis in rainbow trout juveniles (Oncorhynchus mykiss). Aquaculture 2005; 248: 163-72.

[74] Holm JC, Refstie T, B $\varnothing \mathrm{S}$. The effect of fish density and feeding regimes on individual growth rate and mortality in rainbow trout (Oncorhynchus mykiss). Aquaculture 1990; 9: 252-32.

[75] Procarione LS, Barry TP, Malison JA. Effects of high rearing densities and loading rates on the growth and stress responses of juvenile rainbow trout. N Am J Aquacult 1999; 61: 91-6.

[76] Jeong KS, Takeuchi T, Watanabe T. Improvement of nutritional quality of carbohydrate ingredients by extrusion processes in diets of red seabream. Bull Jap Soc Sci Fish 1991; 57: 1543-9.
[77] Cheng ZJ, Hardy RW. Effects of extrusion processing of feed ingredients on apparent digestibility coefficients of nutrients for rainbow trout (Oncorhynchus mykiss). Aquacult Nutr 2003; 9: 77-83.

[78] Glencross B, Hawkins W, Evans D, et al. A comparison of the effect of diet extrusion or screw-press pelleting on the digestibility of grain protein products when fed to rainbow trout (Oncorhynchus mykiss). Aquaculture 2011; 312: 154-61.

[79] Watanabe T, Takeuchi T, Satoh S, Kiron V. Digestible crude protein contents of various feedstuffs determined with four freshwater species. Fish Sci 1996; 62: 278-82.

[80] Watanabe T, Takeuchi T, Satoh S, Kiron V. Methodological influences and mode of calculation. Fish Sci 1996; 62: 288-92.

[81] Azevedo PA, Cho CY, Leeson S, Bureau DP. Effects of feeding level and water temperature on growth, nutrient energy utilization and waste outputs of rainbow trout (Oncorhynchus mykiss). Aquat Living Resour 1998; 11: 227-38.

[82] FAO. The State of the World Fisheries and Aquaculture. Rome, Italy: Food and Agriculture Organization; 2009 [cited 2011 May 2011] Available from: http://www.fao.org/docrep/011/i0250e/i0250e00.HTM.

[83] Tacon AGJ, Metian M. Global overview of the use of fish meal and fish oil in industrially compounded aquafeeds: Trends and future prospects. Aquaculture 2008; 285: 146-58.

[84] Hardy RW. Utilization of plant proteins in fish diets: effects of global demand and supplies of fishmeal. Aquacult Res 2010; 41: 770-6.

[85] Satia BP. Quantitative protein requirements of rainbow trout. Prog Fish-Cult 1974; 36: 80-5.

[86] Kim KI, Kayes TB, Amundson CH. Purified diet development and reevaluation of the dietary protein requirement of fingerling rainbow trout. (Oncorhynchus mykiss). Aquaculture 1991; 96: 57-67.

[87] Barrows FT, Gaylord TG, Sealey WM, Porter L, Smith CE. The effect of vitamin premix in extruded plant-based and fish-meal based diets on growth efficiency and health of rainbow trout, Oncorhynchus mykiss. Aquaculture 2008; 283: 148-55.

Received: December 03, 2011

Revised: January 07, 2012

Accepted: January 09, 2012

(C) Barnes et al.; Licensee Bentham Open.

This is an open access article licensed under the terms of the Creative Commons Attribution Non-Commercial License (http://creativecommons.org/licenses/ by-nc/3.0/) which permits unrestricted, non-commercial use, distribution and reproduction in any medium, provided the work is properly cited. 